\title{
ПОКАЗНИКИ ЛІПІДНОГО ОБМІНУ У ДІТЕЙ ТА ЇХ ВЗАЄМОЗВ'ЯЗОК ІЗ ЗАБЕЗПЕЧЕНІСТЮ BITAMIHOM D
}

\author{
Національний медичний університет імені О. О. Богомольця
}

РЕзюмЕ. Доведено, що функції вітаміну D (VD) не обмежуються тільки контролем кальцій-фосфорного обміну, вивчаються його інші плейотропні ефекти.

Мета - вивчення VD-статусу і його впливу на ліпідний профіль у дітей з групи ризику розвитку дисліпопротеїнемії.

Матеріал і методи. Обстежено 30 дітей віком 6-7 років, які народилися у жінок з цукровим діабетом (ЦД). Контрольна група - 30 дітей від здорових матерів. Проводили оцінку фізичного розвитку з розрахунком індексу маси тіла (IMT). Досліджували показники ліпідного обміну - загальний холестерин (ХС), тригліцериди (ТГ), XС лПВЩ, ХС лПНЩ (ммоль/л) у крові, індекс атерогенності (IA). Усім дітям визначали вміст 25-ОН-Д в сироватці крові, рівень глюкози.

Результати. 10 (33,3 \%) дітей від матерів з ЦД мають надлишкову масу тіла, 5 (16,7 \%) - ожиріння, що в 2 рази вище, ніж у контрольній групі. Рівень глюкози натще у всіх обстежених дітей від матерів з ЦД був у межах фізіологічних коливань. Рівень 25-ОН-Д у дітей від матерів з ЦД, у порівнянні з контрольною групою, був значно знижений.

У дітей від матерів з ЦД виявлено дисліпопротеїнемію: достовірне підвищення вмісту ТГ і ХС у сироватці крові, більш високі показники ХС лПнщ і низькі показники XС лПВщ, ніж у контрольній групі ( $p<0,05)$, IA був достовірно вище.

Висновки. Дефіцит VD в організмі обстежених може бути однією з причин виявленої у них дисліпідемії, крім того, надлишкова маса і ожиріння також $є$ факторами ризику розвитку атеросклерозу, метаболічного синдрому.

КлючОВІ СлОВА: діти; цукровий діабет; дисліпопротеїнемія; ожиріння; холестерин; вітамін Д; індекс атерогенності.

Вступ. На сьогодні проведено багато досліджень з вивчення забезпеченості організму людини вітаміном D (VD) та його біологічної ролі в організмі.

Доведено, що функції VD не обмежуються тільки контролем кальцій-фосфорного обміну, вивчаються й інші його плейотропні ефекти [8].

Активна форма VD бере участь у регуляції клітинної диференціації, проліферації, апоптозу, тим самим гальмує пухлинний ріст; стимулює синтез інсуліну $\beta$-клітинами підшлункової залози і збільшує чутливість клітин організму людини до інсуліну, регулює функцію Т- і В-лімфоцитів, макрофагів, прозапальних цитокінів. Результати масштабних наукових досліджень останніх років вказують на його важливу роль у розвитку метаболічного синдрому, ендокринних порушень, в тому числі цукрового діабету 1 і 2 типів, алергічних, автоімунних, серцево-судинних захворювань у дітей [7].

Популяційні дослідження, що проводяться в світі, дозволили встановити, що поширення недостатності й дефіциту VD сягає епідемічного рівня. Так, при обстеженні дорослого населення України зазначено, що тільки 4,6 \% жителів мають рівень VD в межах норми, у 13,6\% - недостатність, у 81,1 \% - дефіцит VD. Популяційних досліджень поширеності дефіциту VD у дітей в Україні не проводилося, але, за даними деяких авторів, його частота становить 88,5 \% у дітей шкільного віку [2].
3 огляду на перераховане вище, подальше вивчення VD-статусу в дітей різного віку та його плейотропних ефектів $\epsilon$ перспективним.

Метою нашого дослідження було вивчення VD-статусу і його можливого впливу на ліпідний профіль у дітей з групи ризику розвитку дисліпопротеїнемії.

Матеріал і методи дослідження. Ми комплексно обстежили 30 дітей віком 6-7 років, які народилися у жінок, що страждають на цукровий діабет (ЦД). В якості контрольної групи обстежено 30 дітей, які народилися у здорових матерів.

Дітям проводили вимірювання антропометричних показників (зріст, маса), розрахунок індексу

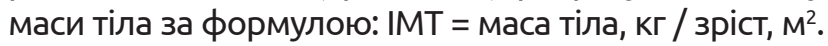
Антропометрію проводили за стандартною методикою з точністю до 0,1 см для зросту і 0,1 кг для

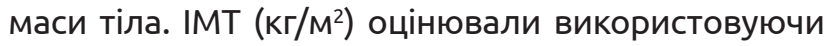
перцентильні криві з урахуванням стандартних відхилень (СВ) для певного віку і статі. Ожиріння у дітей діагностували при IMT >95 перцентиля (від +2 до +3 CВ), надлишкову масу - при IMT у межах 85-95 перцентиля (від +1 до +3 СВ).

У дітей вивчали показники ліпідного обміну загальний холестерин (ХС), тригліцериди (ТГ), ХС лПВЩ, ХС ЛПнЩ (ммоль/л) в крові ферментативно-колориметричним методом з використанням наборів фірми Roche Diagnostics (Швейцарія) на аналізаторі Cobas 6000. 
Огляди літератури, оригінальні дослідження, погляд на проблему, випадок з практики, короткі повідомлення

Індекс атерогенності (IA) визначали непрямим розрахунковим методом за формулою А. Н. Климова: IA = (XC - ХС ЛПВЩ) / ХС ЛПВЩ.

Якісна оцінка показників ліпідного профілю була проведена відповідно до адаптованих критеріїв NCEP / ATP III і ADF.

Крім того, оцінювали стан вуглеводного обміну за рівнем глюкози в крові ферментним гексокіназним методом.

Вміст 25-ОН-Д у сироватці крові визначали імуноферментним методом набором 25-OH-Vitamin D-ELISA (BioVendor, Німеччина) відповідно до інструкції фірми-виробника.

Результати й обговорення. При оцінці стану здоров'я дітей, які перебували під наглядом, враховували дані сімейного анамнезу, відомості про стан здоров'я, тяжкість ЦД у матері і ступінь компенсації вуглеводного обміну, а також особливості перебігу вагітності та пологів.

Відомо, що 16 (53,3 \%) жінок страждали ЦД 1-го типу, 12 (40 \%) - 2-го типу, у 2 (6,6 \%) був гестаційний ЦД. Обтяжений акушерсько-гінекологічний анамнез виявлено у 24 (80 \%) жінок (мимовільний аборт, передчасні пологи, безпліддя, аборти за медичними показаннями, антенатальна загибель плода). У всіх матерів обстежених дітей ЦД поєднувався з іншими хронічними захворюваннями - гіпертонічною хворобою, хронічним панкреатитом, холециститом, виразковою хворобою дванадцятипалої кишки. Як показав аналіз історій розвитку дітей, 20 (66,6 \%) дітей народилися шляхом кесарського розтину, 23 (76,6 \%) - в легкій асфіксії, 5 (16,7 \%) - середній; у 4 (13,3 \%) відзначався респіраторний дистрес-синдром на фоні ателектазів легень, 7 (23,3 \%) дітей народилися недоношеними, всі діти мали ознаки діабетичної фетопатії.

Необхідно зазначити, що 80 \% обстежених нами дітей часто хворіли на респіраторні вірусні інфекції - 10 і більше разів протягом року, мали ускладнення у вигляді синуситу, пневмонії, отиту. Більшу частину обстежених дітей становив контингент з вогнищами хронічної інфекції - хронічний тонзиліт діагностований у 10 (33,3 \%) дітей, аденоїдні вегетації II-III ступеня - у 10 (33,3 \%) дітей.
Як показали результати клінічних досліджень, серед усіх захворювань у дітей, які народилися від матерів з ЦД, високу питому вагу має патологія травної системи. У 80 \% обстежених дітей була дисфункція біліарної системи, у 23,3 \% - функціональна диспепсія.

Оцінка фізичного розвитку досліджуваних дітей показала, що 10 (33,3 \%) дітей від матерів із ЦД мають надлишкову масу тіла, 5 (16,7 \%) - ожиріння. Причому 23,3 \% матерів обстежених дітей також страждали ожирінням, у багатьох дітей надлишкову масу також мали найближчі родичі по материнській лінії. Необхідно зазначити, що в контрольній групі кількість дітей з надмірною масою тіла була значно меншою, ніж у групі дітей від матерів з ЦД (всього 5 дітей - 16,7 \%), ожиріння діагностовано у 2 дітей $(6,6 \%)$.

Нами було вивчено стан вуглеводного обміну у дітей від матерів з ЦД і у дітей контрольної групи. Рівень глюкози натще у всіх обстежених дітей від матерів з ЦД був у межах фізіологічних коливань і не відрізнявся від такого у дітей здорових матерів.

Дослідження забезпеченості VD показало, що рівень його транспортної форми 25-ОН-Д у дітей від матерів з ЦД, порівняно з контрольною групою, був значно знижений і становив 19,63 нг/мл (у дітей здорових жінок - 32,3 нг/мл). Це вказує на виражений дефіцит цього активного метаболіту VD, його транспортної форми в організмі у дітей від матерів із ЦД.

Можливо, що дефіцит VD може бути результатом недостатності харчування, яке не відповідає підвищеним потребам організму, що росте, зменшенням його синтезу в шкірі, порушень обміну в результаті функціональних змін в органахмішенях тощо.

При дослідженні показників ліпідного обміну виявлено значне їх порушення в групі дітей від матерів із ЦД (табл. 1). Згідно з нашими даними, у обстежених дітей виявлено дисліпопротеїнемію: достовірне підвищення вмісту ТГ і ХС у сироватці крові в порівнянні з контрольною групою.

Таблиця 1. Показники ліпідного обміну у дітей віком 6-7 років, які народилися від матерів, хворих на цукровий діабет $(\mathrm{M} \pm \mathrm{m})$

\begin{tabular}{|l|c|c|}
\hline \multicolumn{1}{|c|}{ Показники } & Діти від матерів 3 ЦД, & $\begin{array}{c}\text { Контрольна група, } \\
\mathrm{n}=30\end{array}$ \\
\hline Тригліцериди, ммоль/л & $3,2 \pm 0,15^{*}$ & $1,9 \pm 0,12$ \\
\hline ХС, ммоль/л & $8,7 \pm 0,9 *$ & $5,1 \pm 0.8$ \\
\hline ХС лПВЩ, ммоль/л & $1,48 \pm 0,11^{*}$ & $2,07 \pm 0,16$ \\
\hline ХС лПНЩ, ммоль/л & $2,44 \pm 0,19^{*}$ & $1,46 \pm 0,13$ \\
\hline ІА, ум. од. & $4,8 *$ & 1,46 \\
\hline
\end{tabular}

Примітка. Різниця достовірна $(p<0,05)$. 
Огляди літератури, оригінальні дослідження, погляд на проблему, випадок з практики, короткі повідомлення

Аналіз ліпідного спектра сироватки крові показав, що у дітей від матерів з ЦД вищі показники ХС ЛПНЩ і нижчі показники ХС ЛПВЩ, ніж у дітей 3 контрольної групи $(p<0,05)$. ІА був достовірно вищим у групі дітей від матерів з ЦД.

Дослідження вмісту 25-ОН-Д у дітей від матерів із ЦД виявило його дефіцит в сироватці крові, порівняно з контрольною групою.

Вивчення ліпідного обміну показало підвищення рівнів ТГ, ХС, ХС ЛПНЩ, а також зниження ХС лпвщ.

На сьогоднішній час відомий регулюючий вплив VD на всі обмінні процеси в організмі, включаючи синтез білків, ліпідів, клітинних гормонів, в тому числі інсуліну. Крім того, VD позитивно впливає на функціональну активність ряду тканинних ферментів і гормонів шляхом модифікації ліпідного складу клітинних і субклітинних мембран [6].

Тому ми вважаємо, що дефіцит VD в організмі обстежених дітей може бути однією з причин виявлених у них дисліпідемій. Згідно з результатами наших досліджень, у дітей від матерів з ЦД ми діагностували надлишкову масу тіла в 2 рази частіше, ніж у контрольній групі, а ожиріння - в 2,5 раза частіше, і це також може бути одним із факторів розвитку порушень ліпідного обміну. За даними літератури, ожиріння і надмірна маса тіла достовірно збільшують ризик дисліпідемій, частіше у вигляді зниження рівня ХС ЛПВЩ, що має місце у наших пацієнтів [1].

Відомо, що дисліпідемія супроводжується відкладанням холестерину, тригліцеридів в інтимі судин, унаслідок чого формуються атероматозні бляшки. Атерогенні властивості мають лпнщ, а також аполіпопротеїд В. ЛПВЩ, навпаки, беруть участь у так званому зворотному транспорті холестерину, забираючи його з плазматичних мембран клітин і транспортуючи в печінку. Кінцевий же ефект буде залежати від співвідношення цих класів ліпопротеїдів, а точніше - від величини співвідношення холестерину, який входить до складу ЛПВЩ і ЛПНЩ - так званий ІА. Високий вміст у сироватці крові ХС ЛПНЩ при низькому вмісті XС лПвЩ $\epsilon$ важливим фактором розвитку атеросклерозу [3].

У нашому дослідженні IA був достовірно вищим у групі дітей від матерів із ЦД, що дозволяє віднести їх до групи ризику.
Ряд проведених досліджень останніх років демонструють зв'язок рівнів VD із несприятливими змінами ліпідного профілю. Встановлена пряма кореляція значень 25-ОН-Д з показниками ЛПВЩ, а також негативна - з рівнями лПнЩ і тригліцеридів. Дослідження останніх років свідчать про те, що високі рівні 25-ОН-Д обумовлюють значне $(p<0,05)$ зниження рівнів тригліцеридів та IA [7].

Фармакотерапія дисліпідемій досить складна. Існує безліч препаратів, які знижують рівень холестерину за рахунок впливу на різні ланки його обміну. Однак більшість цих препаратів не застосовується в дитячому віці через численні побічні ефекти. 3 огляду на все вищевикладене ми вважаємо, що використання VD $€$ перспективним для корекції дисліпідемій у дітей.

На сьогодні в світі тривають дослідження щодо можливостей використання VD в якості ад'ювантної терапії для пацієнтів з гіперхолестеринемією [6]. Крім того, доведено, що VD регулює імунну запальну реакцію в інтимі судин, що також дозволяє використовувати його для профілактики атеросклерозу в групах ризику.

Добре відомо, що наявність ожиріння, гіперліпідемії, артеріальної гіпертензії і порушень вуглеводного обміну $\epsilon$ складовими метаболічного синдрому в дітей, особливо на тлі обтяженої спадковості за ЦД 2-го типу [5]. Однак на ранніх етапах розвитку метаболічний синдром безсимптомний, метаболічні та функціональні зміни виявляють тільки при лабораторних та інструментальних обстеженнях [4]. Тому важливим завданням сімейної медицини $€$ рання діагностика доклінічних стадій метаболічного синдрому простими і доступними методами, особливо серед груп ризику.

Висновки. 1. Діти, які народилися від матерів з ЦД, належать до групи ризику розвитку метаболічного синдрому, атеросклерозу, ЦД.

2. Однією з причин виявлених порушень може бути дефіцит VD.

3. Дітям із групи ризику необхідні динамічне спостереження за антропометричними показниками, контроль IMT, ліпідного і вуглеводного профілю крові, рівня 25-ОН-Д.

Перспективи подальших досліджень полягають у вивченні можливості застосування VD для первинної профілактики і лікування метаболічного синдрому, ЦД у дітей. 
Огляди літератури, оригінальні дослідження, погляд на проблему, випадок з практики, короткі повідомлення ЛІТЕРАТУРА

1. Абатуров О. Є. Асоціація поліморфізму гену лактази з дисліпопротеїдемією при ожирінні у дітей / О. Є. Абатуров, А. О. Нікуліна // Современная педиатрия. - 2017. - № 2(82). - С. 118-121.

2. Абатуров А. Е. Лечение и профилактика недостаточности и дефицита витамина Д у детей и подростков / А. Е. Абатуров, Т. П. Борисова, Е. Л. Кривуша // Здоровье ребенка. - 2015. - № 3 (63). - С. 73-78.

3. Громнацька Н. М. Особливості ліпідного обміну в дітей із метаболічним синдромом / Н. М. Громнацька, С. К. Ткаченко // Здоровье ребенка. - 2014. - № 5 (56). C. $15-20$.

4. Громнацька Н. М. Етіологічні та патогенетичні аспекти метаболічного синдрому у дітей і підлітків, його діагностика, профілактика і лікування : автореф. дис. на здобуття наукового ступеня докт. мед. наук : 14.01 .10 /
Громнацька Наталія Миколаївна. - Львів, 2016. - 36 с.

5. Зелінська Н. Б. Ожиріння та метаболічний синдром у дітей / Н. Б. Зелінська // Клінічна ендокринологія та ендокринна хірургія. - 2013. - № 4(45). - С. 62-72.

6. Значение витамина Д в патогенезе сердечнососудистых заболеваний / В. А. Снежицкий, Л. В Янковская, Э. А. Майлян [та ін.] // Журнал Гродненского государственного медицинского университета. - 2015. № 2. - C. 6-14.

7. Поворознюк В. В. Внескелетные эффекты витамина Д / В. В. Поворознюк, Н. А. Резниченко, Э. А. Майлян // Боль. Суставы. Позвоночник. - 2014. - № 1-2 (13-14). - С. 19-25.

8. Фармакологія вітаміну Д/ І. С. Чекман, І. С. Горчакова, В. В. Бережний [та ін.] // Современная педиатрия. - 2017. - № 2 (82). - С. 28-36.

\title{
REFERENCES
}

1. Abaturov, O.Ye., \& Nikulina, A.O. (2017). Asotsiatsiia polimorfizmu henu laktazy z dyslipoproteidemiieiu pry ozhyrinni u ditei [Association of lactase gene polymorphism with dyslipoproteinemia in obesity in children]. Sovremennaya pediatriya - Modern Pediatrics, 2 (82), 118121 [in Ukrainian].

2. Abaturov, A.Ye., Borisova, T.P., \& Krivusha, Ye.L. (2015). Lecheniye i profilaktika nedostatochnosti i defitsita vitamina $\mathrm{D}$ u detey i podrostkov [Treatment and prevention of vitamin $D$ deficiency and deficiency in children and adolescents]. Zdorovye rebenka - Child's Health, 3 (63), 7378 [in Russian].

3. Hromnatska, N.M., \& Tkachenko, S.K. (2014). Osoblyvosti lipidnoho obminu $v$ ditei iz metabolichnym syndromom [Peculiarities of lipid metabolism in children with metabolic syndrome]. Zdorovye rebenka - Child's Health, 5 (56), 15-20 [in Ukrainian].

4. Hromnatska, N.M. (2016). Etiolohichni ta patohenetychni aspekty metabolichnoho syndromu u ditei i pidlitkiv, yoho diahnostyka, profilaktyka i likuvannia [Etiological and pathogenetic aspects of metabolic syndrome in children and adolescents, its diagnosis, prevention and treat-

ment]. Doctor's thesis. Lviv [in Ukrainian].

5. Zelinska, N.B. (2013). Ozhyrinnia ta metabolichnyi syndrom u ditei [Obesity and metabolic syndrome in children]. Klinichna endokrynolohiia ta endokrynna khirurhiia Clinical Endocrinology and Endocrine Surgery, 4 (45), 62-72 [in Ukrainian].

6. Snezhitskiy, V.A., Yankovskaya, L.V., \& Maylyan, E.A. (2015). Znacheniye vitamina D v patogeneze serdechno-sosudistykh zabolevaniy [The value of vitamin $D$ in the pathogenesis in the pathogenesis of cardiovascular diseases]. Zhurnal Grodnenskogo gosudarstvennogo meditsinskogo universiteta - Journal of Grodno State Medical University, 2, 6-14 [in Russian].

7. Povoroznyuk, V.V., Reznichenko, N.A., \& Maylyan, E.A. (2014). Vneskeletnyye effekty vitamina D [Extra-skeletal effects of vitamin D]. Bol. Sustavy. Pozvonochnik. - Pain. Joints. Spine, 1-2 (13-14), 19-25 [in Russian].

8. Horchakova, I.S., Berezhnyy, V.V., \& Davydyuk, A.V. (2017). Farmakolohiia vitaminu D [Pharmacology of vitamin D]. Sovremennaya pediatriya-Modern Pediatrics, 2 (82), 28-36 [in Ukrainian].

\section{ПОКАЗАТЕЛИ ЛИПИДНОГО ОБМЕНА У ДЕТЕЙ И ИХ ВЗАИМОСВЯЗЬ С ОБЕСПЕЧЕННОСТЬЮ ВИТАМИНОМ D}

СЕ. А. Строй, Л. В. Слипачук

\author{
Национальный медицинский университет имени А. А. Богомольца
}

PEЗЮME. Доказано, что функции витамина D (VD) не ограничиваются только контролем кальций-фосфорного обмена, а именно изучаются его другие плейотропные эффекты.

Цель - изучение VD-статуса и его возможного влияния на липидный профиль у детей из группы риска по развитию дислипопротеинемий. Обследовано 30 детей в возрасте 6-7 лет, которые родились у женщин, страдающих сахарным диабетом (СД). Контрольная группа - 30 детей от здоровых матерей. Проводили оценку физического развития с расчетом индекса массы тела (ИМТ). Исследовали показатели липидного обмена - общий холестерин (ХС), триглицериды (ТГ), ХС ЛПВП, ХС ЛПНП (ммоль/л) в крови, индекс атерогенности. Всем детям определяли содержание 25-ОН-Д в сыворотке крови, уровень глюкозы. 
Огляди літератури, оригінальні дослідження, погляд на проблему, випадок з практики, короткі повідомлення

Результаты. 10 (33,3 \%) детей от матерей с СД имеют избыточную массу тела, 5 (16,7 \%) - ожирение, что в 2 раза больше, чем в контрольной группе.

Уровень глюкозы натощак у всех обследованных детей от матерей с СД был в пределах физиологических колебаний. Уровень 25-ОН-Д у детей от матерей с СД, по сравнению с контрольной группой, был значительно снижен.

У детей от матерей з СД выявлена дислипопротеинемия: достоверное повышение содержания ТГ и ХС в сыворотке крови, более высокие показатели ХС лПНП и низкие показатели ХС ЛПВП, чем В контрольной группе $(p<0,05)$, ІА был достоверно выше.

Выводы. Дефицит VD в организме обследованных может быть одной из причин виявленной у них дислипидемии, кроме того, избыточная масса и ожирение также являются факторами риска развития атеросклероза, метаболического синдрома.

КЛЮЧЕВЫЕ СЛОВА: дети; сахарный диабет; дислипопротеидемия; ожирение; холестерин; витамин Д; индекс атерогенности.

\section{INDICATORS OF LIPID METABOLISM IN CHILDREN AND THEIR RELATIONSHIP WITH VITAMIN D}

\section{O. Bohomolets National Medical University}

๑O. A. Stroy, L. V. Slipachuk

SUMMARY. It has been proven that the functions of vitamin D (VD) are not limited to the control of calcium-phosphorus metabolism, but its other pleiotropic effects are being studied.

The aim - to learn VD status and its effect on the lipid profile in children of risk group for the development of dyslipoproteinemia.

30 children aged 6-7 years who were born to women with diabetes were examined. The control group - 30 children 6-7 years old from healthy mothers. As assessment of physical development was carried out with the calculation of body mass index. We studied lipid metabolism indicators - total cholesterol, triglycerides, high density lipoprotein cholesterol, low density lipoprotein cholesterol $(\mathrm{mmol} / \mathrm{l})$ in blood, atherogenic index. All children were determined with the content of $25-\mathrm{OH}-\mathrm{D}$ in the serum, the level of glucose.

Results. 10 (33.3\%) children from mothers with diabetes were overweight, 5 (16.7 \%) - obesity, which is 2 times higher than in the control group.

The fasting glucose level in all the examined children from mothers with diabetes was within physiological fluctuations. The level of 25-OH-D in children from mothers with diabetes mellitus, compared with the control group, was significantly reduced.

Dyslipoproteinemia was found in children from diabetes mothers: a significant increase in serum triglyceride and cholesterol levels higher levels of low-density lipoprotein cholesterol and lower levels of high-density lipoprotein cholesterol than in the control group $(p<0,05)$, atherogenic index was significantly higher.

VD deficiency in the body of the surveyed can be one of the causes of their dyslipidemia, in additions, overweight and obesity are also risk factors for the development of atherosclerosis, metabolic syndrome.

KEY WORDS: children; diabetes; dyslipoproteinemia; obesity; cholesterol; vitamin D; lipoproteins; atherogenic index.

Отримано 12.06.2020 